\title{
“COVID-19” PANDEMIC: RETHINKING DEFENCE SPENDING IN BULGARIA
}

\author{
Atanas Dimitrov ${ }^{1}$ \\ e-mail:adimitrov@unwe.bg
}

\begin{abstract}
This paper investigates defence spending in Bulgaria in the context of the COVID-19 pandemic. It analyses military expenditures on both regional and national scales and tries to compare the post-financial and economic crisis period of the first decade of the $21^{\text {st }}$ century to the current pandemic situation. The paper argues that it is unlikely that the ever evolving threat landscape will lead to a significant decrease in defence spending, while requiring its rethinking in Bulgaria with a focus on investments in technologies and related activities. Due to the ongoing pandemic and the fact that relatively little time has passed since its emergence, part of the conclusions drawn are primarily prospective in nature.

Key words: defence spending, pandemic, COVID-19, military expenditure, defence budget

JEL: F50, H56, H60

\section{Introduction}

While in recent years many states were trying to find a solution to irregular migration or other problems in some sectors of their economies, since March 2020 the health sector has been proving to be the one that has affected the integrity of all other activities in almost every country in the world. On $11^{\text {th }}$ March 2020, the World Health Organization (WHO) declared COVID-19 pandemic (World Health Organization, 2020), which quickly led to the imposition of a number of restrictive measures around the world, most of which similar in nature, and which have had a huge impact on the economy at the national, regional and global levels. The World Bank (2021, pp. 3-4) estimates that the global economy shrank by $4.3 \%$ in 2020 , while in the same year the European Union (EU) gross domestic product (GDP) fell by $6.8 \%$ (Eurostat, 2021a). These data raise a number of questions, including the one on how to redirect limited available resources and on which sectors should be prioritized at the expense of others, while keeping in mind many other challenges, for example the visible dissatisfaction of many citizens and businesses.
\end{abstract}

1 Senior Assist., PhD, Department of National and Regional Security, University of National and World Economy 
The pandemic-related situation is in the forefront in Bulgaria too. According to preliminary data of the National Statistical Institute of the Republic of Bulgaria $(2021$, p. 1), in 2020 GDP of the country decreased in real terms by $4.2 \%$ compared to 2019. The pandemic was also one of the most discussed political topics, especially in view of the parliamentary elections held in April 2021. In such a context, defence spending remained in the background. In general, the circumstances in the security environment suggest that healthcare, education and tourism should be leading in terms of support, investment and recovery. That is why this article is trying to answer the questions "What impact the current pandemic situation has had so far and will have on the Bulgarian defence expenditures?" and "Should it be seen differently in the years ahead?". In fact, the impact of the COVID-19 pandemic on the defence sector has been poorly studied, which can be justified by its ongoing course and related accompanying ambiguities. This in turn accounts for certain limitations to the scope of the current study, especially with regard to the considered period of impact of the pandemic and the related restrictive measures. This is also true for the comparison between the nowadays economic hardship and the negative economic consequences of the financial and economic crisis at the end of the first decade of the $21^{\text {st }}$ century. Hence, the main sources of information on which limited in scope (short-term) predictions can be made about the impact of the current pandemic on military spending are various statistical databases such as the Stockholm International Peace Research Institute (SIPRI) databases and the North Atlantic Treaty Organization (NATO) information on defence expenditures of its member countries (NATO, 2021a). The paper is also trying to contribute to the further and deeper examination of defence expenditures in Bulgaria in times of crisis such as the current one.

\section{Literature review}

Defence spending is an area of particular interest to researchers (see for example Schmidt, 1987; Looney, 1988; Elveren, 2019) and political actors. This is mainly due to the fact that it is often involved in political disputes over budget allocations, parliamentary and presidential elections, military campaigns and other important issues for society. Although there are different definitions of the term defence spending, among the most cited ones are those of SIPRI and NATO. According to the former, "military expenditure include all spending on current and capital expenditure on (1) the armed forces, including peace keeping forces; (2) defence ministries and other government agencies engaged in defence projects; (3) paramilitary forces when judged to be trained, equipped and available for military operations; (4) military space activities forces and activities" (SIPRI, n.d.). As for the NATO definition, defence expenditure are assumed as "payments by a national government actually made, or to be made, during the course of the 
fiscal year to meet the needs of its armed forces, those of Allies or of the Alliance" (NATO, 2020).

Defence expenditures are frequently seen as an opportunity for increased employment while at the same time they are in constant competition with other sectors of the national economy. Their role in economic growth, however, is still a highly debated and contested topic (for example, Ram, 1995; Ivanov, 2002; 2006). Dunne and Tian (2013, p. 8) note that one particular clear thing about military expenditure is that ,in general they come at an economic cost $t^{\prime \prime}$.

Defence spending and its reduction in times of crisis are used by political actors to gain votes and influence. For instance, they can be defined as very useful in maintaining and/or creating jobs, or as harmful to society in the case of increasing military expenditures at the expense of budgetary resources for other sectors such as healthcare or education (Sandler, Hartley, 1995, pp. 287-288). Generally speaking, defence expenditure is a complex field of study due to the lack of transparency and information on defence, including military industries, which, in turn often involves a political-strategic dimension (Herrera, Gentilucci, 2013).

As of April 2021, the issue of the impact of the COVID-19 pandemic and related restrictive measures on defence spending has been poorly studied worldwide. The main reason for this is that the pandemic is not over and the impact can currently be seen mainly in the short term. According to Meyer et al (2021, p. 10), the pandemic has the potential to change the way security and defence are perceived in the EU, identifying three channels through which this can be done in practice - by infecting staff working on the Common Security and Defence Policy (CSDP), including in individual countries; through the domestic and foreign policies of individual countries in response to the pandemic and its consequences; and through civil society, non-state groups and individuals who respond to the crisis and the difference in their perception of risks and opportunities (for example, through the higher or lower levels of public trust in the state and in its actions during the pandemic).

Tan (2020, p. 30) suggests that the negative economic impact of the pandemic will limit defence spending only in the short term, while in the medium and long term other dynamics driving the arms trade will be of importance, such as tensions along the China-US axis. In other words, military expenditure do not depend only on economic data. The defence spending demand is usually defined by economic, political and military features (Fritz-Abmus, Zimmerman, 1990, cited in Fonfría, Marín, 2012, p. 14).

In Bulgaria, the study of the impact of the COVID-19 pandemic is also very limited. The debate on more or less defence expenditures comes mainly under the sign of political struggles, which in the last few months could be regarded as part of an election campaign, taking into account the parliamentary elections held 
on 4th April 2021. In this respect, Tagarev (2020, p. 74) notes that any reduction of the military budget or the postponement of the implementation of the plan for its increase will delay rearmament and divert valuable resources, hindering the contribution of the Bulgarian armed forces to NATO and EU operations and initiatives.

There is, however, a relatively extensive literature on the relationship between economic crises and defence spending. This is largely influenced by periods of economic hardship, the expected NATO and EU membership and later on by Bulgaria's accession to these regional organizations. Dimitrov (1999, p. 4) states that with the end of the Cold war and the dismantlement of the Warsaw Pact, in the early 1990s new economic circumstances emerged based on which the defence expenditures had to compete for resources on an equal footing with the other public sectors. Although a new economic environment was in place, in the 1990s, the military industrial complex in Bulgaria was still regarded by many, including defence producers, as "the ultimate hope for overcoming the then economic crisis" (Dimitrov, 2002, p. 49).

In the $21^{\text {st }}$ century the financial and economic crisis of $2008-2009$ played again a role in the country's defence expenditures, by bringing about the significant decrease of the defence budget. Tsonkov (2013, p. 96) points out that the economic crisis was a main problem in striking the balance between the budget and defence capabilities of the Bulgarian army as well as in achieving a high level of effective defence resource management. However, Tagarev and Velkova (2014, p. 1) argue that this decrease was in line with other NATO members' actions in this regard, and was also due to the more stable security environment.

\section{Defence spending during the COVID-19 pandemic}

The rapid development of technology and communications, along with armed conflicts and terrorism, are normally expected to cause constant changes in the security environment, which in turn drives up defence and security spending in many countries, a trend especially visible in recent years. The European Defence Agency (2021, p. 4), for example, points out that the defence spending of its 26 member states has been steadily rising over the last five years, reaching $€ 186$ billion in 2019 , that is, $1.4 \%$ of their GDP and $2.9 \%$ of their total government spending. Against this background the COVID-19 pandemic raises the question of its potential negative impact on defence spending, given that in addition to the health crisis, an economic one is expected to follow. In this line of thought, the global economic and financial crisis from the end of the first decade of this century had an adverse impact on the economic performance of many countries. This was true also in the case of military expenditures with a steady decline between 2009 and 2014 (EDA, 2021, p. 4), which in turn suggests that from this perspective a similar period can 
be expected in the next few years, given the impact of the pandemic and related restrictive measures at the national, regional and global levels.

The European Defence Fund sheds some light on what can be expected in this regard. Its budget of 13 billion euros for the period $2021-2027$ was initially proposed in 2018 by the European Commission (European Commission, 2018), but it was later contested due to the economic difficulties in the context of the pandemic. For this reason, in June 2020 a budget of 7.953 billion euro (7.104 billion euro at constant prices for 2018) was proposed and in December 2020 the European Parliament and the Council approved it.

However, it should be noted that despite the deteriorating economic performance in many countries around the world due to the situation related to the COVID-19 pandemic, as well as the expectations that it will have a negative impact on military expenditures, in some states the latter actually increased in 2020. Globally, defence spending reached $\$ 1.83$ trillion, a 3.9\% annual increase in real terms. As a share of GDP, they increased from an average of $1.85 \%$ in 2019 to $2.08 \%$ in 2020 , as military budgets were maintained despite severe economic contractions caused by the pandemic and the related restrictive measures (McGerty, 2021).

In Europe, the total European defence spending increased by $2 \%$ in real terms in 2020 (McGerty, 2021), although differently across the countries. Especially significant is the change in military expenditures in Sweden, where in December 2020, a $40 \%$ increase for the $2021-2025$ period was approved, the highest one in the last 70 years (Keyton, 2020). As for NATO, all member states, with the exception of Bulgaria, increased their defence spending in the same year (NATO, 2020). Yet it should be mentioned that in the case of Bulgaria there was a decrease only compared to 2019 , when the country set a record in its military expenditures since joining NATO (fig. 1). In other words, Bulgaria is no exception to the general trend of increasing defence spending over the past few years. In 2019 it even exceeded 3\% of GDP, although basically this was due to the purchase of F-16 Block 70 aircrafts. Against this background, it should be stressed that the global financial and economic crisis had a tangible negative impact on Bulgarian defence expenditures (fig. 1), and only in the last two years certain steps have been taken to increase them and reach NATO's $2 \%$ defence investment guideline.

To some extent the impact in this regard can be attributed to the National Plan for Increasing the Defence Spending to 2\% of the Gross Domestic Product until 2024, adopted in 2017. However, according to this document, military expenditures should reach 2\% of the GDP in 2024 in a gradual way (Ministerski savet, 2017). Instead, this aim was achieved in 2019, posing questions about the political circumstances behind it. 


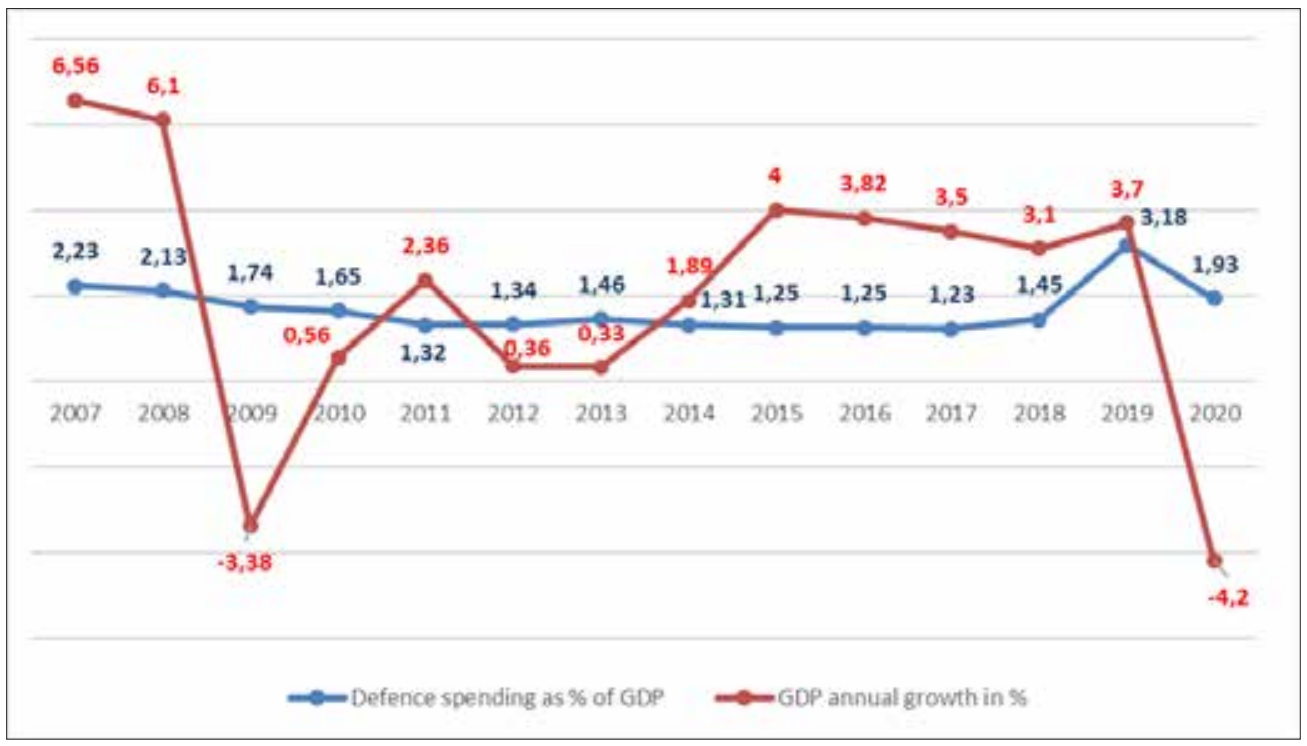

Source: NATO (2020), SIPRI (2021), National Statistical Institute of Bulgaria (2021).

Figure 1: Defence expenditure in Bulgaria as a percentage of GDP and annual GDP growth in $\%$ in the period $2007-2020$

Moreover, in October 2020, the then minister of defence of the Republic of Bulgaria Krassimir Karakachanov stated that "despite the crisis with COVID-19 and the possible impact on the country's economy, the Ministry of Defence continues to work on major projects to modernize the Bulgarian Army", noting that investing in the defence sector boosts job creation, "achieved through the development of industrial cooperation with leading companies in the military-industrial complex" (Ministerstvo na otbranata, 2020a). This statement came in the spirit of the opponents of disarmament and the reduction of military spending, highlighting the possible negative impact on cities and regions in which companies from the defence industry are located.

However, the smaller size of the Ministry of Defence budget in 2021 compared to the previous two years is certainly visible, and so are the relatively small funds provided in the budget program "Research and Technology", given the importance of this field globally. The latter increases compared to previous years, but minimally - from BGN 9.22 million in 2019 and BGN 9.76 million in 2020² to almost BGN 11

${ }^{2}$ According to the Report on the implementation of the budget of the Ministry of Defence with quarterly information on the expenditures under budget programs 31.12.2020, the actual costs under Major Program 10 "Research and Development" in 2020 amounted to BGN 11541000. 
million in 2021 (Ministerstvo na otbranata, 2021). Although the budget programme "Research and technologies" costs have increased several times since the economic and financial crisis of 2008-2009, their amount can nevertheless be regarded as too small in a time of rapid technological development. Besides, this increase reflects to a large extent the personnel-related costs (figure 2).

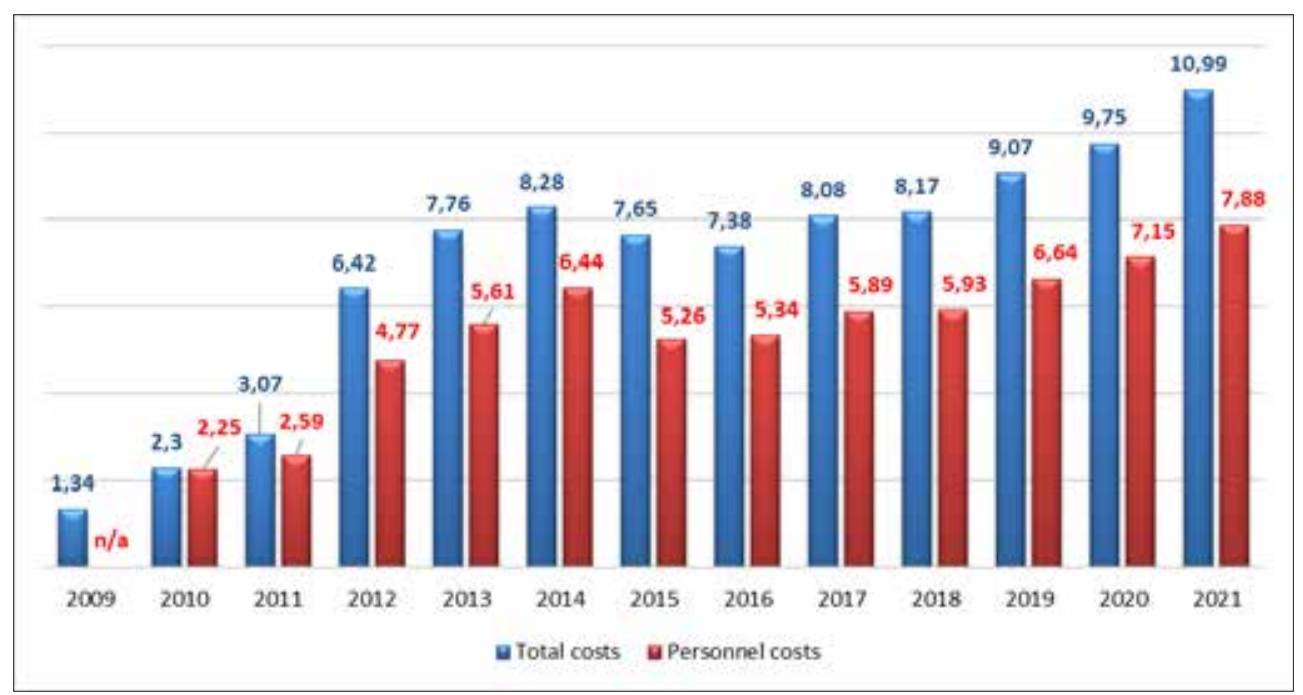

Source: Ministry of Defence of the Republic of Bulgaria (2009-2021).

Figure 2: Research and Technology Budget Program of the Ministry of Defence of the Republic of Bulgaria in BGN millions $(2009-2021)$

It should be added that the pandemic is affecting the country's defence capabilities and potential not only through changes in defence spending. The pandemic has also affected the preparation and certification of some formations of the country's armed forces in the context of NATO and the CSDP. In one particular case, the COVID-19 infection led to postponing the Bulgarian participation in a NATO multinational naval exercise in the Black Sea (Nikolov, 2021). In addition, as early as the first half of 2020, the implementation of some scheduled forms of preparation was postponed and was to be carried out later in the same year or in 2021 (Ministerstvo na otbranata, 2020b, p. 15). These delays in the training of the Armed Forces of the Republic of Bulgaria have the potential to reduce the ability to perform tasks and the interoperability with partner countries within NATO and the EU. However, with regard to the participation in operations and missions in support of international peace and security, in the short term the pandemic will rather have a limited negative impact on Bulgaria's involvement, given the country's modest presence in such operations and missions at present. 


\section{Discussion}

Provided that the difference in defence spending before and during the pandemic is not significant or there is even a significant increase, several questions arise. For example, "Is this at the expense of other sectors of the economy?" and "Are certain areas of defence spending changing, such as increased resource allocation for cybersecurity and for the development and use of artificial intelligence?". The answers to these questions are inevitably related to rethinking defence expenditures in general.

Even though it is necessary to hold debates on the higher or lower levels of military expenditures, what is very important but rarely discussed in public pertains to their distribution among different programs within a budget. For instance, Eurostat data show that about half of the defence spending of the 27 EU Member States in 2019 is for staff salaries and corresponding social security contributions, while significantly less - 19\% - are capital investments such as for example for new equipment (Eurostat, 2021b).

What is more, in contrast to total defence spending, which in 2019 exceeded the 2007 levels, investment in defence research and technology recovered much more slowly, and amounted to approximately EUR 400 million less in the same year. In addition, member states collectively fail to meet the collective criterion of spending $2 \%$ of their total defence expenditure on defence research and development (European Defence Agency, 2021). On the one hand, this may suggest some expectations about the development of the defence sector after the end of the pandemic, at least in the short term. Thus, for the most part, the costs associated with military personnel in many EU countries, including Bulgaria, will be maintained, while investments in new technologies and equipment are not expected to increase significantly (and are likely to even decrease in some cases). In the case of Bulgaria (and not only) such a trend could also be expected in terms of participation in peace operations and missions.

What should also be taken into account is that very often defence programmes are multiannual, and can therefore include previously committed expenditure for future periods (Fonfría, Marín, 2012, p. 16). Hence in the event of an economic crisis, good budgetary management becomes even more important, considering that possible mistakes are more visible and have the potential to lead to political instability. Due to its nature, in times of crisis the defence sector often falls within the scope of debates for less allocated resources at the expense of other areas of the economy. At such times, however, it is important not to make very drastic changes, especially if contractual commitments have been made in previous years, that is, to increase defence expenditures. Penchev (2017, p. 25) notes that in 2010 the Bulgarian Ministry of Defence made a serious mistake after initially reducing the cost of purchasing weapons to BGN 10 million amid the financial 
and economic crisis, and then revising the budget and increasing it by BGN 300 million to meet commitments made in previous years. In this line of thought, it should be highlighted that national defence aims to provide external security and thus contribute to long-term economic growth, or in other words, defence expenditures may have an adverse effect on current economic growth, yet they are not necessarily harmful or too high (Ram, 1995, p. 253).

Apart from defence expenditures, the COVID-19 pandemic has affected the world in many other aspects. The World Bank estimates that between 88 and 115 million people will be pushed into extreme poverty due to the pandemic, bringing their total number globally to between 703 and 729 million (World Bank, 2020). It also emphasizes that the pandemic situation is creating deep income inequality, threatening the achievement of economic recovery and future growth in a number of regions (World Bank, 2020). In addition, 370 million children have had no access to nutritious meals as schools were shut in almost 200 countries in April 2020 as part of the restrictive measures related to the spread of COVID-19 (World Food Programme, 2020, p. 16). All this, in turn, can be seen as a precondition for the emergence or further aggravating of armed conflicts, which directly affect the international security environment. What is more, poverty and social inequality are often seen as factors for the strong presence of organized crime and terrorist or other armed groups across different regions. In other words, it is likely that the current pandemic will deepen some of the already existing challenges to international peace and security. As a result it is unlikely that any significant decrease in military budgets in the coming years will be witnessed, especially in countries directly affected by armed conflicts or terrorist activities. Although Bulgaria cannot currently be seen among them, it is a transit country for many refugees and migrants apart from being a member of NATO and the EU. Given the current economic and social background of Bulgaria, new security and economic shocks in the Middle East in the coming few years can easily become a serious challenge to the country in a number of aspects.

In addition to the above-stated, the international security environment is affected by other factors as well. Cyber security is a growing field that along with many opportunities, poses a number of security threats. In his annual report, NATO Secretary General Jens Stoltenberg acknowledges the increasing role of malicious cyber activity in 2020, including misinformation, hacking, and espionage, which are facilitated by the pandemic and technological changes such as the introduction of $5 \mathrm{G}$ wireless communications and the growing acceptance of connected devices (NATO, 2021b, p. 23). The pandemic has further created cyber security gaps as many companies and even state institutions have switched to working from home. 
Against this background, what should Bulgaria do in terms of defence expenditures, assuming the global nature of the security environment and taking into account the significant changes that have already begun within it? With regard to this, in February 2021, the former minister of defence Velizar Shalamanov noted that Bulgaria needs a new rearmament program worth over BGN 15 billion with a clear focus on technology (Shalamanov, 2021). Also, in the National Cyber Security strategy "Cyber Sustainable Bulgaria 2020", adopted in 2016, cyberattacks and impacts through cyberspace are identified as an essential element of modern hybrid warfare models (Ministerski savet, 2016, p. 43).

Furthermore, Tagarev (2019, p. 186) notes that threats in the digital society are shifting from conventional military operations to cyber security. However, it is highly likely that more technologies will mean less human involvement, that is, less personnel employed. In the case of Bulgaria, this will be a significant challenge as the biggest part of the military budget is allocated to meeting personnel needs such as salaries. Put simply, if smart technology and the Internet of Things (IoT) are widely embedded, we can expect social tensions, for the concept of IoT and intelligent technology shrinks human labour to a significant extent (Tagarev, 2019, pp. 188-189).

Since cutting costs and life-saving may be identified as the main positive aspects of automation in the defence sector, in the long run Bulgaria will not remain far from such changes. Yet, the country should decide if it will be among the leading states in this regard and face up to the new security environment and realities or else, whether it will assume the role to follow suit. Either way, the country should be prepared in terms of job openings and retraining of military personnel in order to respond to the technological advancements in the defence and security sector. It will also mean that Bulgaria should not decrease its defence expenditure and will probably have to invest more in defence technologies. This is important not only from the perspective of job security and possible social tensions within the country. It is also crucial that Bulgaria does not fall behind current and potential adversaries in terms of technological developments, including automation and artificial intelligence (AI). In fact, the global AI and robotics defence systems market is expected to increase significantly, driven now also by the COVID-19 pandemic. Taking into account the above-mentioned, it has to be further noted that investments in technologies should be regarded as purchases from abroad and own production.

Despite these clear signals and features of the current security environment, since the end of the totalitarian regime in Bulgaria, almost every single government that has been in power has avoided reforms that would have taken a long time to yield some significant positive results. Instead, they have predominantly preferred to carry out projects the outcome of which becomes evident within the 
respective term in office, so that these results could be taken advantage of in the following election campaign. This has been especially visible in the last decade.

The security environment and the global advance of technology suggest that it is time that Bulgaria should start making significant investments in cyber security and defence technologies, thus making a further step into the new reality we are living in. Although defence expenditures are often politically driven, the evolving threat landscape requires a clear understanding and vision that their decrease or poor resource management is unlikely to bring benefits to Bulgaria, apart from possible gains from some short-term political goals, such as improving election odds.

\section{Concluding remarks}

The security environment is a subject to constant changes caused by events and factors of different nature. In the past century the two world wars and the socalled Cold War have been identified as such, while in the $21^{\text {st }}$ century, these are, for example, the terrorist attacks of $11^{\text {th }}$ September 2001, the Arab Spring, and China's economic and technological boom. Against this background, the COVID-19 pandemic has the potential to change the security environment, among other possible effects. The ongoing pandemic and the related restrictive measures have inflicted significant damage to the world economy, including in Bulgaria. A number of sectors have been affected, albeit to varying degrees. In such a situation, however, defence spending remains rather unaffected. On the one hand, this is due to the agreements already made in previous periods, and, on the other hand, to the ongoing pandemic. The latter is narrowed mainly to the very short timeframe in order to make more specific assessments about defence expenditures. In fact, the COVID-19 pandemic impact is likely to be measured in a few years. The impact will be gauged not only in terms of the higher or lower levels of spending on defence and security in general, but also in the way we perceive threats and how we can counter them.

Generally, maintaining or increasing defence spending can be seen positively in the light of preserving/creating jobs, but also negatively when it comes to competing for budgetary funds with other important sectors such as healthcare and education. This is particularly true for Bulgaria where the benefits from the membership in the EU and NATO are still debated.

Given the constant changes in the security environment, Bulgaria should not significantly reduce defence spending, repeating the situation after the global financial crisis. This does not mean investing in seemingly political projects. Instead investments should be made in accordance with the needs of the Bulgarian Armed Forces and the country, including the need for interoperability with partner countries and for technological and resource provision. 
Finally, defence expenditures in Bulgaria should reflect the rapid pace of technological advancement worldwide, as well the resulting globalisation and open societies. Therefore, Bulgaria should invest a lot more in research and technology activities when it comes to its security.

\section{References}

Иванов, Т. (2006). Икономически аспекти на трансформацията на националния сектор за сигурност и отбрана, Икономически алтернативи, бр. 4. (Ivanov, T., 2006, Ikonomicheski aspekti na transformatsiyata na natsionalnia sektor za sigurnost i otbrana, Ikonomicheski alternativi, br. 4).

Министерски съвет. (2017). Национален план за повишаване на разходите за отбрана на $2 \%$ от брутния вътрешен продукт на Република България до 2024 г. (Ministerski savet, 2017, Natsionalen plan za povishavane na razhodite za otbrana na $2 \%$ ot brutnia vatreshen produkt na Republika Bulgaria do 2024 g.), available at: https://www.mod.bg/bg/doc/cooperation/20181005_ Natsionalen_plan_BG.pdf (accessed 6 April 2021)

Министерство на отбраната. (2020а). Министьр Красимир Каракачанов: Подписаната „Пьтна карта за сътрудничество между Република България и САЩ в областта на отбраната“" ще подпомогне развитието на българските Въоръжени сили, 7 октомври. (Ministerstvo na otbranata, 2020a, Ministar Krasimir Karakachanov: Podpisanata „Patna karta za satrudnichestvo mezhdu Republika Bulgaria i SASht v oblastta na otbranata" shte podpomogne razvitieto na balgarskite Vaorazheni sili, 7 oktomvri), available at: https:// www.mod.bg/bg/news.php?\&fn_page=16 (accessed 16 March 2021)

Министерство на отбраната. (2020b). Резюме на Отчет за степента на изпълнение на политиките и отбранителните програми на Министерството на отбраната, структурите на пряко подчинение на министьра на отбраната и Българската армия през първото шестмесечие на 2020 г. (Ministerstvo na otbranata, 2020b, Rezyume na Otchet za stepenta na izpalnenie na politikite i otbranitelnite programi na Ministerstvoto na otbranata, strukturite na pryako podchinenie na ministara na otbranata i Balgarskata armia prez parvoto shestmesechie na 2020 g.), available at: https://www.mod.bg/bg/ doc/budj_planove_prognozi_otcheti/20200929_Rezume_otchet_MO_I_ polugodie_2020.pdf (accessed 5 April 2021)

Министерство на отбраната. (2021). Бюджет на Министерството на отбраната по бюджетни програми утвърдени със Закона за държавния бюджет на Република България за 2021 г., разходи по области на политики, функционални области и/или бюджетни програми за 2021 г. (Ministerstvo na otbranata, 2021, Byudzhet na Ministerstvoto na otbranata po byudzhetni programi utvardeni sas Zakona za darzhavnia byudzhet na Republika Bulgaria 
za 2021 g., razhodi po oblasti na politiki, funktsionalni oblasti i/ili byudzhetni programi za 2021 g.), available at: https://www.mod.bg/bg/doc/budj_planove prognozi_otcheti/20210112_Byudjet_MO_2021.pdf (accessed 5 April 2021) Пенчев, Г. (2017). Разходи за отбрана и разпределение на бюджета, Авангард Прима, София. (Penchev, G., 2017, Razhodi za otbrana i razpredelenie na byudzheta, Avangard Prima, Sofia).

Цонков, Н. (2013). Средата на сигурност на България и перспективи за развитие на политиката й за сигурност, Военен журнал, бр. 3, с. 92-98 (Tsonkov, N., 2013, Sredata na sigurnost na Bulgaria i perspektivi za razvitie na politikata y za sigurnost. Voenen zhurnal. br. 3, s. 92-98).

Шаламанов, В. (2021). България няма крайно необходимата програма за превъорьжаване, Интервю за Bloomberg TV Bulgaria [online], (Shalamanov, V., 2021, Bulgaria nyama krayno neobhodimata programa za prevaorazhavane, Intervyu za Bloomberg TV Bulgaria), available at: https:// www.bloombergtv.bg/a/19-svetat-e-biznes/89512-balgariya-nyama-kraynoneobhodimata-programa-za-prevaorazhavane (accessed 3 April 2021)

Dimitrov, D. (1999). Civil-Military Relations and defence budgeting in Bulgaria, Harmonie Paper 6, The Centre for European Security Studies.

Dimitrov, D. (2002). The Restructuring and Conversion of the Bulgarian Defence Industry during the Transition Period, BICC Paper 22, Bonn International Center for Conversion, Bonn.

Dunne, J. P. and Tian, N. (2013). Military expenditure and economic growth: A survey, The Economics of Peace and Security Journal, Vol. 8, No. 1. http:// dx.doi.org/10.15355/epsj.8.1.5.

European Commission. (2018). EU budget: Stepping up the EU's role as a security and defence provider, Press release, 13 June, available at: https://ec.europa. eu/commission/presscorner/detail/en/IP_18_4121 (accessed 17 March 2021)

European Defence Agency. (2021). Defence Data 2018 - 2019: Key findings and analysis, doi:10.2836/189276

Eurostat. (2021a). GDP down by $0.7 \%$ in the euro area and by $0.5 \%$ in the EU: Preliminary flash estimate for the fourth quarter of 2020, February, available at: https://ec.europa.eu/eurostat/documents/portlet_file_entry/2995521/202022021-AP-EN.pdf/0e84de9c-0462-6868-df3e-dbacaad9f49f (accessed 19 March 2021)

Eurostat. (2021b). Government expenditure on defence. available at: https:// ec.europa.eu/eurostat/statistics-explained/index.php/Government expenditure_on_defence\#Expenditure_on_.27defence.27 (accessed on $1 \overline{2}$ March 2021) 
Fonfría, A., \& Marín, R. (2012). Determinants of the demand for defence expenditure in the NATO countires, Journal of the Higher School of National Defense Studies, 12, pp. 9-30.

Fritz-Abmus, D. and Zimmerman, K. (1990). West German demand for defence spending, in Hartley, K. and Sandler, T., The economics of defence spending: an international survey, Routledge, London and New York, pp. 118-147.

Herrera, R. \& Gentilucci, E. (2013). Military spending, technical progress, and economic growth: a critical overview on mainstream defense economics, Journal of Innovation Economics \& Management, 2(2), pp. 13-35, https://doi. org/10.3917/jie.012.0013.

Keyton, D. (2020). Sweden ups defense budget $40 \%$ due to regional tensions, The Associated Press, 15 December, available at: https://apnews.com/article/ sweden-russia-baltic-sea-d8e5bacdcd7c96d38f2fde5afe8794bc (accessed 10 April 2021)

McGerty, F. (2021). Global defence-spending on the up, despite economic crunch, Military Block Balance, 25 February, available at: https://www.iiss.org/blogs/ military-balance/2021/02/global-defence-spending-increases (accessed 31 March 2021)

Meyer, C. et al. (2021). How the COVID-19 crisis has affected security and defence-related aspects of the EU, Policy Department for External Relations, Directorate General for External Policies of the Union PE 653.623, January, doi:10.2861/93636.

NSI. (2021). Gross domestic product for the fourth quarter of 2020 and 2020 (preliminary data), 9 March, available at: https://www.nsi.bg/sites/default/ files/files/pressreleases/GDP2020q4_en_Q54HAIH.pdf (accessed 13 April 2021)

NATO. (2020). Defence Expenditure of NATO Countries (2013 - 2020), 21 October, available at: https://www.nato.int/cps/en/natohq/news_178975.htm (accessed 3 April 2021)

NATO. (2021a). Information on defence expenditures, 11 June, available at: https://www.nato.int/cps/en/natohq/topics_49198.htm (accessed 11 September 2021)

NATO. (2021b). The Secretary General's Annual Report 2020, 16 March, available at: https://www.nato.int/cps/en/natohq/opinions_182236.htm (accessed 10 April 2021)

Nikolov, K. (2021). Bulgaria misses start of NATO naval exercise due to COVID-19, Euroactiv.com, 1 March, available at: https://www.euractiv.com/section/politics/short_news/bulgaria-misses-start-of-nato-naval-exercise-due-tocovid-19/ (accessed 13 April 2021) 
Ram, R. (1995). Defense expenditure and economic growth, Handbook of defense economics, 1, pp. 251-274.

Sandler, T. \& Hartley, K. (1995). The economics of defense, Cambridge University Press.

SIPRI. (n.d.). SIPRI Definition of military expenditure, available at: https://www. sipri.org/databases/milex/definitions (accessed 16 March 2021)

SIPRI. (n.d.). SIPRI databases, available: https://www.sipri.org/databases (accessed 11 September 2021)

SIPRI. (2021). Military expenditure by country as percentage of gross domestic product, 1988-2020, available at: https://www.sipri.org/databases/milex

Tagarev, N. (2019). Defence Resource Planning in the Environment of the Internet of Things, Nauchni trudove, Vol. 1, Publishing Complex - UNWE, pp. 169-197, available at: http://unwe-research-papers.org/uploads/ResearchPapers/RP_vol1_2019_No07_N\%20Tagarev.pdf (accessed 12 April 2021)

Tagarev, T. (2020). Balancing Defense and Civil Support Tasks: The Impact of Covid-19 on the Bulgarian Military's Roles, Connections, 19(2), pp. 61-76, available at: https://connections-qj.org/article/balancing-defense-and-civilsupport-tasks-impact-covid-19-bulgarian-militarys-roles (accessed 5 April 2021)

Tagarev, T. \& Velkova, L. (2014). Scenarios for Resource Allocation to Bulgaria's Defense in the Horizon of 2035, Journal of Defence Management 4: 119. doi:10.4172/2167-0374.1000119

Tan, A. T. (ed.). (2020). Research Handbook on the Arms Trade, Edward Elgar Publishing.

World Bank. (2021). Global Economic Prospects. January 2021. Washington, DC: World Bank. doi: 10.1596/978-1-4648-1612-3

World Bank. (2020). Poverty and Shared Prosperity 2020: Reversals of Fortune. Washington, DC: World Bank, doi: 10.1596/978-1-4648-1602-4

World Food Programme. (2020). State of School Feeding Worldwide 2020, Rome, available at: https://www.wfp.org/publications/state-school-feedingworldwide-2020 (accessed 12 April 2021)

World Health Organization. (2020). WHO Director-General's opening remarks at the media briefing on COVID-19 - 11 March 2020, available at: https://www. who.int/director-general/speeches/detail/who-director-general-s-opening-remarks-at-the-media-briefing-on-covid-19---11-march-2020 